\title{
D'Alembert's Contribution to the French Enlightenment
}

\author{
Tingting Liu ${ }^{1} \&$ Haibin Sun ${ }^{1}$ \\ ${ }^{1}$ College of Physics and Electronic Engineering, Taishan University, Tai' an, Shandong, 271000, China \\ Correspondence: Tingting Liu, College of Physics and Electronic Engineering, Taishan University, Tai'an, \\ Shandong, China.
}

Received: October 14, 2021

Accepted: November 8, 2021

Online Published: December 31, 2021

doi:10.5539/mas.v16n1p17

URL: https://doi.org/10.5539/mas.v16n1p17

\begin{abstract}
The French Enlightenment directly influenced and promoted the Enlightenment in other European countries. During the Enlightenment, the development of natural science and the dissemination of scientific knowledge greatly promoted the emancipation of human minds. D'Alembert is a famous French mathematician, physicist, astronomer, and philosopher. As a representative on mission during the French Enlightenment, d'Alembert made important contributions to mechanics, mathematics, and astronomy that greatly promoted the development of natural sciences.
\end{abstract}

Keywords: d'Alembert, the Enlightenment, Encyclopédie

\section{Introduction}

The 17th and 18th centuries witnessed the increasingly powerful economy of the emerging bourgeoisie in Europe. However, the feudal dictatorship seriously hindered the development of capitalism, and the emerging bourgeoisie urgently demanded the overthrow of the old system. During the same period, science and technology rapidly developed in Europe, and new natural science theories provided people with new weapons of thought. Many scholars at that time advocated scientific experiments and the study of the objective laws of nature. The development of natural science and the spread of scientific knowledge freed people from the shackles of Scholasticism and promoted the liberation of human thought. These constituted the soil that bred the Enlightenment (Suenaga, 2020).

The Enlightenment originated in Britain, and France later became its centre (Withers, 2020). At the beginning of the 18th century, France was at the peak of its autocracy, and its feudal system had become rotten. Worse, the oppression and exploitation from the two privileged classes, the nobles and the monks, were deepening whereas the emerging bourgeoisie, which held some economic power, remained in a politically and economically suppressed position. Additionally, the broad masses of working people were living in dire straits, and social contradictions were intensifying and difficult to reconcile. These changes were the historical roots of the rise of the French Enlightenment. Voltaire (1694-1778) was the leading figure of the French Enlightenment, and other scholars such as Rousseau (1712-1778), Montesquieu (1689-1775), Diderot, and d'Alembert were outstanding representatives of the Enlightenment. D'Alembert was not only a scientist but also a writer, an encyclopedist, and a philosopher (Guilbaud \& Schmit, 2017). The French Enlightenment (a) directly influenced and promoted the Enlightenment in European countries; (b) powerfully affected the feudal autocracy and its spiritual pillar, the Catholic Church; (c) gradually brought the revolution of people's thinking to a climax; and (d) laid a solid foundation for the bourgeois revolution (Simonyi, 2012). This paper focuses on the essential contributions of d'Alembert, one of the figures in the French Enlightenment, and introduces his contributions to the fields of mechanics and mathematics as well as his participation in the compilation of the Encyclopédie.

The outline of this paper is as follows: Section 2 introduces d'Alembert's main scientific contributions. Section 3 introduces his work in the process of publishing and editing the Encyclopédie. Section 4 briefly introduces d'Alembert's argument with Rousseau over d'Alembert's "Geneva" entry for the Encyclopédie. The final section provides the conclusion.

\section{D'Alembert's Main Scientific Contributions}

Jean le Rond d'Alembert, a famous French mathematician, physicist, astronomer, and philosopher, was born in Paris, France, to an officer and an aristocrat on November 17, 1717. In 1729, d'Alembert entered the Collège Mazarin, where he studied philosophy, law, medicine, and art. Moreover, he independently studied mathematical 
and physical works by scientists such as Newton and Descartes (Capecchi, 2021). In 1739, d'Alembert submitted a paper on integral operations to the Académie des Sciences (the French Academy of Sciences), and this paper became recognized by mathematician A. C. Clairaut. In 1740, d'Alembert submitted a paper on the motion of solids in liquids to the Académie des Sciences. During May 1741, d'Alembert was elected an assistant member of astronomy at the Académie des Sciences for his outstanding scientific talent. In 1746, he was promoted to associate member of mathematics. In 1747, d'Alembert published a paper on the deduction of the general causes of wind, for which he received a prize from the Berlin Academy of Sciences and was elected a member of that institution. In November 1754, d'Alembert was elected a member of the Académie des Sciences and became a permanent under-secretary of state (Guilbaud \& Schmit, 2017; Simonyi, 2012). Personal attacks by his opponents gradually led to d'Alembert's removal from the encyclopedia before the relationship completely ended in 1758 (Capecchi, 2021).

Mechanics was one of d'Alembert's main research interests. He made an important contribution to the establishment of the Newtonian system of mechanics in 1743, upon publishing his Traité de dynamique (Treatise on Dynamics); this monograph was the first overview of Newtonian mechanics in France and made d'Alembert one of the most prestigious scholars in Europe (Crépel, 2005). D'Alembert tended to treat mechanics as a branch of mathematics and believed that mechanics should be deduced based on a small number of axioms. In the preface to Traité de dynamique, d'Alembert provided a judgment on the 17th- and18th-century controversy over the measures of motion (i.e., momentum $m v$ and vis viva $m v^{2}$ ). According to d'Alembert, the force of a moving object can be expressed only in terms of the object's ability to overcome an impediment, and momentum can be used as a measure of the force of a moving object in cases where the object's impedance was sufficient to decelerate the object, stop its motion in a split second, and bring the object to equilibrium. Moreover, he noted that both measures were valid and asked, "If the measure of force differs in equilibrium and in decelerating motion, what is the inconvenience?" Additionally, D'Alembert vaguely mentioned the relationship between the change in momentum and the time of action of the force and the relationship between the change in vis viva and the distance the object moves. Ultimately, d'Alembert did not find an essential difference between the two measures of motion. It was only after the concepts of energy and energy conversion and the law of the conservation of energy were established in the 19th century that Engels, using the viewpoint of dialectical materialism, revealed the essential difference between the two measures through an in-depth analysis of the change in the form of motion (Haibin, 2007). In this book, d'Alembert distilled the entirety of mechanics into three principles - namely, inertial forces, compositional motion, and equilibrium — and provided proofs for each of them. The book also covered the general principles used to solve the dynamics of particle systems. D'Alembert viewed the equations of motion expressed by Newton's second law as a system of forces in equilibrium at each instant (i.e., $\boldsymbol{F}+[-m a]=0$ ), creating a method that is now called d'Alembert's principle. The introduction of this principle simplified the analysis of some mechanical problems and laid the foundation for analytical mechanics (Dugas, 2012; Rojo \& Bloch, 2018)

D'Alembert had a broad range of research interests, and mathematics was one of his most-researched realms. As a primary pioneer and founder of mathematical analysis, D'Alembert published an eight-volume series, called Opuscules mathématiques, representing his mathematical contributions. He also studied astronomy, and his contributions encompassed the theory of the shape and rotation of the earth and the theory of the motion of the moon. From 1754 to 1756, d'Alembert published three volumes of Recherches sur différents points importants $d u$ système $d u$ monde, which systematically elaborated on his theory of celestial mechanics. Furthermore, d'Alembert contributed to the establishment of fluid mechanics. He published Traite de l'equilibre et du mouvement des fluides in 1744 and Essai d'une nouvelle théorie de la résistance des fluides in 1752. Additionally, he carried out in-depth research on harmonics. Furthermore, d'Alembert published Essai sur les éléments de philosophie, Éléments de musique, and two volumes of Mélanges de littérature, de philosophie et d'histoire (Capecchi, 2021).

\section{D'Alembert and the Publication of the Encyclopédie}

In the mid-18th century, the French Enlightenment reached its climax, which was marked by the editing and publication of the Systematic Dictionary of the Sciences, Arts, and Crafts (known as the Encyclopédie). Denis Diderot (1713-1784) was hired to begin editing the Encyclopédie in 1745 (Montminy, 2017). According to Diderot, the purpose of the Encyclopédie was "to bring together the various kinds of knowledge scattered through the world, to expound their universal system to those who live with us at the present time, and to transmit this book to our posterity, so that the achievements of past ages may not be a useless thing for future ages, and that our descendants can be more moral and also happier because they are more knowledgeable, so that us to be worthy of the title of mankind when we die with the world." This objective is in line with the aims of the 
Enlightenment. The Encyclopédie focuses on humanism and aims to promote the happiness of humankind and the progress of human society, as Diderot conveyed in an Encyclopédie entry: "Man is the unique telos from which we should start and to which we should trace everything. If you object my existence and the happiness of my fellow-creatures, what has the rest of nature outside of me to do with me?"

In 1746, Diderot invited d'Alembert to be the deputy editor of the Encyclopédie and to write the mathematics and natural sciences entries. From then on, d'Alembert devoted himself to the great French Enlightenment. In his preface to the Encyclopédie, d'Alembert proposed his scientific views, declaring his adherence to materialism. At that time, Diderot and d'Alembert gathered many famous French scholars, such as Voltaire, Montesquieu, Rousseau, Condorcet, Holbach, and Buffon, to participate in the compilation of the Encyclopédie, thus forming the famous Encyclopédistes (Encyclopedists); Diderot and d'Alembert became the representative figures of this group. The Encyclopédistes adhered to the materialist outlook and advocated science, believing that science could reasonably explain natural and social phenomena and promote the progress of human civilization. As a result, the Encyclopédistes became the backbone of the French Scientistic Movement. In the Encyclopédie, the Encyclopédistes severely criticized and rejected religious theology. Consequently, the government and the church banned this book, and Diderot and the publishers were arrested and imprisoned. Hence, most of the volumes were compiled in secret. The first volume of the Encyclopédie was published in 1751; by 1772, a total of 28 volumes had been published: 17 in the main edition and 11 in the illustrated edition, all of which were edited by Diderot. From 1775 to 1800, Condorcet succeeded Diderot as the encyclopedia's editor, producing five additional volumes of supplements and two volumes of indexes (Crépel, 2005).

The Encyclopédie provides a systematic summary, based on the highest level of philosophy and natural science of the time, of all fields of science and technology and covering almost all scientific achievements of Europeans up to the middle of the 18th century. Dividing human knowledge into three main categories - science, art, and technology - the Encyclopédie provides a systematic and detailed account of the natural scientific knowledge, technology, and processes that humankind had acquired. After its publication, the Encyclopédie became the best-selling book in France. It introduced the scientific and technological achievements of humankind in easy-to-understand language, played an active role in the dissemination of scientific knowledge and democratic ideas, and created a favourable atmosphere for the development of science. The encyclopedia served as a collection of enlightened ideas from enlightened thinkers in various fields of the French Enlightenment during the 18th century, turning the earlier scattered publicity into a bloc shock and launching a comprehensive attack on the feudal economic base and superstructure under science and democracy. Furthermore, the Encyclopédie combated religious power and autocratic rule and swept across the old traditions, ideas, and culture symbiotic with the feudal system, laying the ideological foundation of the French Revolution. In 1789, the Bourgeois Revolution broke out in France. Condorcet, an important representative of the Encyclopédistes, joined the revolution and was elected to the revolutionary government as a member of the court. The revolution's two "Declarations of the Rights of Man" declared that human rights were the natural (i.e., inherent) rights of human beings, including "equality, liberty, security and property." The four major rights manifested the ideals of the Encyclopédistes.

\section{D'Alembert, Rousseau and the Dispute over the Geneva Entry in Encyclopédie}

Born in Geneva to a family of watchmakers, Jean-Jacques Rousseau (1712-1778) lived in poverty and wanderlust during his youth. In 1751, he rose to fame with the publication of Discours sur les sciences et les arts (Discourse on the Arts and Sciences), which caused a great sensation in Europe. In 1752, his opera Le devin du village (The Village Soothsayer) was performed to great success at the royal court of Fontainebleau. Rousseau returned to Geneva in 1754, where he was warmly welcomed and became a citizen. Rousseau wrote treatises such as Discours sur l'origine et les fondements de l'inégalité parmi les hommes (Discourse on the Origin and Basis of Inequality Among Men), Du contrat social (The Social Contract), Émile (On Education), and Julie, ou la nouvelle Héloïse (Julie, or the New Eloise). He believed that human beings originally were equal in nature (i.e., in primitive times) and that the root of inequality lied in the emergence of the idea of private property. The idea of equality was the core of Rousseau's thinking. Nevertheless, he did not advocate a return to primitive society; instead, he called for a balance between rich and poor and the protection of the interests of small producers. Rousseau's doctrine reflected the aspirations of the petty bourgeoisie and had a revolutionary element. His views were easily shared by all classes of the time and profoundly influenced the later revolutions of the workers and peasants and the progress of the big bourgeoisie (Dent, 2017; Larrère, 2011).

In August 1756, d'Alembert traveled to Geneva to conduct research for the entry on Geneva in the seventh volume of the Encyclopédie. During his time in Geneva, d'Alembert stayed at the home of Voltaire, a keen lover of the theatre who was, at the time, engaged in a fierce struggle against the Church to organize public 
performances of plays. During the Age of Enlightenment, Enlightenment thinkers rejected the asceticism of Christianity and treated the theatre as an effective way to popularize civilization and oppose religion, whereas the Church, which considered theatre as offending public decency, opposed its public performances. Thus, d'Alembert was obviously influenced by Voltaire's ideas when he wrote the Geneva entry, in which he ostensibly praised Geneva for its education, democracy, and prosperity demonstrated by its proud universities and libraries and its thriving industries. However, he also expressed surprise at the Church's denigration and prohibition of theatrical performances and praised priests who did not believe in Christian doctrine. D'Alembert suggested that Geneva should, like Paris, have a theatre because the theatre would glorify the customs and enable the Genevans to learn both the Macedonians' wisdom and the Athenians' elegance and politeness. The publication of his entry on Geneva caused an uproar, and the Swiss Church was so outraged that the authorities established a special commission to declare that all priests believed in the doctrine (Façanha et al., 2021).

In December 1757, Rousseau received the seventh volume of the Encyclopédie and was extremely dissatisfied with the entry on Geneva. In March 1758, he published "Lettre à d'Alembert sur les spectacles" ("Letter to M. d'Alembert on Spectacles"), in which he accused and criticized both d'Alembert and the Encyclopédie. Rousseau opposed the establishment of theatres in Geneva, arguing that the theatre hindered people's work, added to their burden, offended social decency, and affected social stability (Larrère, 2011). However, Rousseau had become famous for his play Le devin du village. In May 1759, D'Alembert wrote "Letter from M. d'Alembert to M. Jean-Jacques Rousseau," claiming that he still strongly held his opinions and emphasizing that although the primary purpose of theatres was to entertain, they did not prevent people from improving their moral standards. During this time, Voltaire also wrote many articles opposing Rousseau. After this controversy, d'Alembert resigned as editor of the Encyclopédie but continued to provide content for the Encyclopédie's mathematical and natural science entries. In contrast, Rousseau completely separated from the Encyclopédistes (Sullivan \& Balch, 2015).

\section{Conclusions}

Looking back on d'Alembert's life, we know that he has had a broad and lasting interest in natural sciences, and he was good at thinking and summarizing. Like many other brilliant scientists, d'Alembert had excellent scientific literacy as well as good humanistic literacy, including philosophical literacy. This is also an important reason to study and learn from d'Alembert. His advantageous combination of humanistic and scientific literacy led to his great scientific career.

Because of the length limitation, this article only briefly introduces d'Alembert's achievements in the fields of mechanics and mathematics. For d'Alembert's contributions to classical mechanics and his stories with other physicists, readers can refer to the relevant literature (Capecchi, 2021; Dixit et al., 2017; Dugas, 2012). Ultimately, his article emphatically introduces d'Alembert's contribution to the publication of the Encyclopédie and his debate with Rousseau and focuses on the analysis of his important contributions to the French Enlightenment.

\section{Acknowledgments}

This work has been supported by the Teaching Reform Project of Taishan University (SZ202023), First-class Course of Taishan University (Theoretical mechanics) and the Teacher Education Research Special Project of Taishan University (JY-02-202022).

\section{References}

Capecchi, Danilo. (2021). Classical Mechanics. In D. Capecchi (Ed.), Epistemology and Natural Philosophy in the 18th Century: The Roots of Modern Physics (pp. 161-298). Cham: Springer International Publishing. https://doi.org/10.1007/978-3-030-52852-2_3

Crépel, Pierre. (2005). Chapter 11 - Jean Le Rond D'Alembert, Traité de dynamique (1743, 1758). In I. Grattan-Guinness, R. Cooke, L. Corry, P. Crépel \& N. Guicciardini (Eds.), Landmark Writings in Western Mathematics 1640-1940 (pp. 159-167). Amsterdam: Elsevier Science. https://doi.org/10.1016/B978-044450871-3/50092-9

Dent, N. J. H. (2017). Jean-Jacques Rousseau. In Steven M. Emmanuel (Ed.), The Blackwell Guide to the Modern Philosophers: From Descartes to Nietzsche (pp. 201-222). https://doi.org/10.1002/9781405164856.ch10

Dixit Uday Shanker, Hazarika Manjuri, \& Davim, J. Paulo. (2017). History of Mechanics. In U. S. Dixit, M. Hazarika \& J. P. Davim (Eds.), A Brief History of Mechanical Engineering (pp. 47-72). Cham: Springer International Publishing. https://doi.org/10.1007/978-3-319-42916-8_3 
Dugas, René. (2012). A History of Mechanics. New York: Dover Publications.

Façanha, Luciano da Silva, Carvalho, Zilmara de Jesus Viana de, Serra, Maria Olilia, Pires, Helderson Mariani, Tavares, Márcio Junior Montelo, Silva, Priscila de Oliveira, . . . Silva, Nildo Francisco da. (2021). PHILOSOPHY AND THEATRE IN THE CENTURY OF ENLIGHTENMENT: Diderot, Voltaire and Rousseau. International Journal for Innovation Education and Research, 9(7), 69-83. https://doi.org/10.31686/ijier.vo19.iss7.3220

Guilbaud Alexandre, \& Schmit, Christophe. (2017). A historiographical overview of the current state of research into Jean Le Rond D'Alembert (1717-1783). Centaurus, 59(4), $251-262$. https://doi.org/10.1111/1600-0498.12168

Haibin, Sun. (2007). D'Alembert's contribution to science. Mechanics in Engineering, (4), 83-85.

Larrère, Catherine. (2011). Jean-Jacques Rousseau on women and citizenship. History of European Ideas, 37(2), 218-222. https://doi.org/10.1016/j.histeuroideas.2010.10.014

Montminy, Martin. (2017). Denis Diderot. In M. Cameron, B. Hill \& R. J. Stainton (Eds.), Sourcebook in the History of Philosophy of Language: Primary source texts from the Pre-Socratics to Mill (pp. 859-886). Cham: Springer International Publishing. https://doi.org/10.1007/978-3-319-26908-5_34

Rojo Alberto, \& Bloch Anthony. (2018). The principle of least action: history and physics. Cambridge, United Kingdom: Cambridge University Press. https://doi.org/10.1017/9781139021029

Simonyi, Karoly. (2012). A Cultural History of Physics. New York: CRC Press. https://doi.org/10.1201/b11630

Suenaga, Keiichiro. (2020). The 'Industrial Enlightenment' and technological paradigms of the modern steel industry. Technology in Society, 63, 101375. https://doi.org/10.1016/j.techsoc.2020.101375

Sullivan Vickie, \& Balch Katherine. (2015). Spectacles and Sociability: Rousseau's Response in His Letter to d'Alembert to Montesquieu's Treatment of the Theatre and of French and English Society. History of European Ideas, 41(3), 357-374. https://doi.org/10.1080/01916599.2014.974921

Withers, Charles W. J. (2020). Enlightenment Geography. In A. Kobayashi (Ed.), International Encyclopedia of Human Geography (2nd ed.) (pp. 137-149). Oxford: Elsevier. https://doi.org/10.1016/B978-0-08-102295-5.10639-0

\section{Copyrights}

Copyright for this article is retained by the author(s), with first publication rights granted to the journal.

This is an open-access article distributed under the terms and conditions of the Creative Commons Attribution license (http://creativecommons.org/licenses/by/4.0/). 